\title{
Global Higher Education: Development and Implications
}

\author{
Pamela A. Lemoine ${ }^{1}$, Wendi M. Jenkins ${ }^{1} \&$ Michael D. Richardson ${ }^{1}$ \\ ${ }^{1}$ Columbus State University, Columbus, GA, USA \\ Correspondence: Michael D. Richardson, Columbus State University, Columbus, GA, USA.
}

Received: December 10, 2017

Accepted: December 14, 2017 Online Published: December 16, 2017

doi:10.20849/jed.v1i1.253

URL: https://doi.org/10.20849/jed.v1i1.253

\begin{abstract}
Global higher education is experiencing a myriad of challenges that impact the performance and application of education throughout the world. Globalization is a force that encompasses the virtual economy and how knowledge and information are shared and used. Higher education is seen as the primary vehicle for nations to improve the economic conditions for citizens in this new economy. Concurrently, technology has impacted the ability of higher education to respond the multiple difficulties of virtual learning, increased communication efficiency and how to respond to the anytime, anywhere learning demands. Global higher education continues to develop and evolve and global leaders should recognize the essential mission of global higher education to the creation, exchange and implementation of knowledge in a global marketplace.
\end{abstract}

Keywords: globalization, global higher education, virtual economy, technology, virtual learning, marketing higher education

\section{Introduction}

Globalization tends to be something beyond any institution's control - the flow of technology, economy, knowledge, people, values, and ideas across borders (Altbach, 2015; Altbach \& Reisberg, 2015; Ball, Dworkin, \& Vryonides, 2010). Globalization, a key reality in the 21 st century, has already profoundly influenced higher education (Zhu, 2015). Globalization is defined as reality shaped by an increasingly integrated world economy, new information and communications technology, the emergence of an international knowledge network, and other forces beyond the control of higher education institutions (van der Wende, 2003).

Technological changes are occurring at such an accelerating rate that the production of knowledge makes management imperative (Van Vught, 2008). Futurists predict that the education systems of tomorrow will be drastically different from those of today. They forecast that current information about teaching and learning will proliferate and will be used more effectively because of educational technology and telecommunications. However, they add that it might take a century to bring to bear the applications of assessment and evaluation (Staley \& Trinkle, 2011). Concepts of quality in higher education will vary between countries and regions, and the styles of the regional quality will reflect these differences. But perceptions of quality are changing, and the growing emphasis on outcomes and standards heralds the possibility of more dramatic techniques for assessing and evaluating teaching within a global context (Lovette, 2013; Lub, van der Wende, \& Huisman, 2005; Olaniran \& Agnello, 2008; Rogers, 2001).

Traditional universities whose concentration historically has been the production of knowledge in the form of human capital, research, and scholarship, are challenged to tap into the expanding need for lifelong learning (Frank \& Gabler, 2007). While the need for education is growing, the sustainability of all the forms of postsecondary education is a concern (Graves, 2010; Weber \& Duderstadt, 2012). "In all modern contexts", Graves (2010) points out, "education is now the primary vehicle for practicing the principal of social equity (by enabling equal opportunity) and for ensuring collective socioeconomic security and ensuring against its collapse" (p. 28).

Economic and technological changes are occurring at an accelerating rate in the information and communication-based society, making life-long learning for everyone a necessity (Archibald \& Feldman, 2008). This is particularly the case in the transition period from industrial production to a knowledge-based economy. Today's college graduates will change careers multiple times, each change requiring access to lifelong learning with additional education being required at each career change (Bickerstaff \& Cormier, 2015; Graves, 2010). "More people worldwide require more education over their lifetimes in order to secure socioeconomic security 
for themselves, their families, their employers, their governments, and our civilization" (Graves, 2010, p. 29). Access to higher education will be a necessity for job mobility and economic success (Orstein \& Eng, 2015; Walsh, 2011).

Duderstadt (2001), suggested newer university roles were "an engine for economic growth through the generation and application of new knowledge" (p. 5). Colleges and universities, traditionally, are regarded as places to go, land-based institutions where students meet teachers in a face-to-face setting to become informed (Kauppi \& Errkla, 2011). Students emerge from traditional universities certificated and credentialed, necessary tools for upward social and economic mobility (Haskins, 2008; Haskins, Holzer, \& Lerman, 2009; Johnstone, 2004).

However, higher education institutions are facing decreased funding during a time of scarce resources yet increased accountability for productivity in the development and articulation of knowledge (Bok, 2013; Choudaha, Chang, \& Kono, 2013; Heaney, 2009). And, technology has disrupted the traditional, formal processes of higher education (Bates, 2010; Hogan, 2015). Using emerging technologies as an accelerant, higher education institutions are separating from traditional brick and mortar physical spaces and venturing into a virtual mélange of educational models used in the global digital economy (Altbach, 2004; Marginson, 2006, 2000; Slaughter \& Rhoades, 2004).

\section{The Necessity for Higher Education}

Historically, higher education models have approached traditional higher education as a necessity (Spring 2008). Education was class conscious; education was for the elite, and not generally available for women and non-white races. Countries once dependent on British colonial support developed higher educational models to promote their own economies (Spring 2008). Post-war higher education models were promoted by the governing entity. Once marginalized nations used higher education to promote political goals and education; in some countries, higher education became a conduit for violence and religious intolerance (Caminada \& Martin, 2012). Others saw higher education as a venue to address racial inequality and the rights of the marginalized to be educated (Adeoye \& Wentling, 2007; Levin, 2011; Sin \& Kehn, 2013).

Most recently, higher education has become a profitable business framework, an entrepreneurial online business model, and a higher education corporate machine, presenting education as a marketable commodity of knowledge-based products (Marginson, 2007). Embedded in these concepts and, it could be argued, emerging from them, is the perception that access to knowledge and learning is a universal right, one of the key rights of the global community (McMahon, 2009). In fact, knowledge is increasingly regarded as the solution to individual and collective social and economic problems, i.e., a new global religion (Natale \& Doran, 2012). However, this new "religion" now faces inevitable deliberations and debates regarding knowledge imperialism and the new marginalization for those on the edge (Palfreyman, 2010). Those who are successful in the new global knowledge economy may harvest great wealth and exert an inordinate influence on the world's future.

\section{The Globalization of Higher Education}

Researchers predict that 80 percent of new jobs created in the global knowledge driven economy would require advanced education. However, colleges and universities face movement from traditional roles of working to redefining their institutional mission to include innovation and entrepreneurship (Guri-Rosenblit, 2010). Universities are now battling borderless, global competitors moving into the business of education (Teichler, 2004, 2006). To stay viable in the knowledge economy, post-secondary institutions needed to become business-like entrepreneurs by marketing themselves, building collaborative alliances, and preparing for newer, emerging disruptive technologies (Altbach, Reisberg, \& Rumbley, 2009; Shofer \& Meyer, 2006; Teichler, 2006).

Higher education, the right to be educated, to acquire knowledge to overcome poverty, and increase to social position had been called the great equalizer (Coley \& Baker, 2013); however, traditional higher education was not equally accessible by all. Is higher education still the great equalizer, the opportunity to overcome poverty, increase social class, and to become a functional societal member or has that message been subverted (Tooley, 2004)? Others see education as a platform to address racial inequality and the rights of the marginalized to be educated (Bergh \& Nilsson, 2010; Turpin \& Cooper, 2005). In 1948, the United Nations Universal Declaration of Human Rights established education as entitlement for all children; however, changing politics, demographics, and economics have impacted education paradigms (Theodore, 2014).

\section{Changing the Face of Global Higher Education}

Globalization forces higher education institutions to examine their participation in the international environment and to assess their involvement in a transparent world (Altbach \& Knight, 2007). Technology has created a vast 
new expanse of potential markets for higher education in a global market place (Zott, Amit, \& Massa, 2011). Globalization has eradicated some of the typical roles exploited by prior generations. The potential for pluralization of power in global higher education; the mobility of people, information and ideas; will expand the influence of technology, globalization and higher education. Internationalization is defined as the variety of policies and programs that universities and governments implement to respond to globalization (Tomasevski, 2005).

Higher education is increasingly viewed as a major stimulus for both economic and social development (Archibald \& Feldman, 2008). Government tax revenues are not keeping pace with rapidly rising costs of higher education. The expansion of student numbers has presented a major challenge for systems where the tradition has been to provide access to free or highly subsidized tertiary education (Ball, 2012). In financial terms, this has become an unsustainable model, placing pressure on systems to fundamentally restructure the "social contract" between higher education and society at large. Parents and/or students are increasingly responsible for tuition and other fees (Ball, Dworkin, \& Vryonides, 2010). Tuition fees are emerging even in Europe, long the bastion of free public higher education (DiGioacchino \& Sabani, 2009).

Government is ultimately responsible for the development of higher education in every country. The trends are obvious: those countries with the most vibrant higher education systems are those that are most productive (Enders, 2004; Guile, 2001). Both the social and economic futures of countries depend heavily on the educational attainment of their population and are tied to the quality of their higher education institutions (Giroux, 2009). In addition, economic and cultural globalization has ushered in a new era in higher education (Healey, 2008). For the first time in history every research university is part of a single world-wide network and the world leaders in the field have an unprecedented global visibility and power. Research is more internationalized than before and the mobility of faculty has increased (Geenough, McConnaughay, \& Kesan, 2007).

\section{Interpretations of Globalization in Higher Education}

In this era globalization combines economic and cultural change (Beech, 2011). On one hand globalization entails the formation of world-wide markets operating in real time in common financial systems, and unprecedented levels of foreign direct investment and cross-border mobility of production (Bashir, 2007). On the other hand, globalization rests on the first world-wide systems of communications, information, knowledge and culture, tending towards a single world community (Brown, Lauder, \& Ashton, 2008). First, the continuously extending networks based on travel, mobile phones, broad-band Internet and other information and communications technologies (ICTs), are creating new techniques for human association, of unprecedented scale and flexibility; spanning cities and nations with varied cultures and levels of economic development (Demange, Fenge, \& Uebelmesser, 2014; Douglas, King, \& Feller, 2009; Fallis, 2007). And, second, the networks enable the complex data transfers essential to knowledge-intensive production (Feigenbaum \& Iqani, 2015; Goldstein, 2004). The processes of communication and information, where the economic and cultural aspects are drawn together, constitute what is new about globalization; and inclusion/exclusion in relation to ICT networks and knowledge have become key dividing lines in shaping relations of power and inequality (Douglas, King, \& Feller, 2009; Ferreira, Haddad, \& Faria, 2014; Hekkert \& Negro, 2009; Mohrmana, Mab, \& Bakerc, 2008).

\section{Globalization and Economics}

Globalization cannot be regarded simply as a higher form of internationalization, rather, globalization transcends national identities and carries the potential to be actively hostile to nation-states (Teichler, 2006). Much of what begins as internationalization has implications for globalization, and adds to the accumulation of challenges to national policy autarky (Carnoy, 2014). One difference between globalization and internationalization is whether national systems become more integrated as suggested by globalization, or more interconnected as with internationalization (Bement, 2007). But thickening connections readily spill over into the evolution of common systems (Stainer \& Stainer, 2011).

Global higher education is more open than are national systems, with a wide range of opportunities for innovations, alliances and markets (Mok, 2015). To maximize effectiveness in the global environment, on one hand it is essential to retain a strong sense of identity and purpose; on the other hand, it is essential to be open and engaged with others (Stromquist \& Monkman, 2014). At the same time to be effective in the global environment means being prepared to change (Lane, Lemoine, Tinney, \& Richardson, 2014). Global exchange is transformative and all policies and institutional habits are exposed to a global challenge (Secundo, Margherita, Elia, \& Passiante, 2010). Governments in many nations are wrestling with the question of whether competition at home improves competitiveness abroad, and which combination of competition with collaboration will deliver 
the best results (Kaiser, Maassen, Meek, van Vught, de Weert, \& Goedegebuure, 2014; Tannock, 2013).

Globalization with changes in the world's economy, increasing diversity, and the ubiquitous use of technology is effecting all of education, particularly global higher education (Bleiklie, 2005; Rivzi \& Lingard, 2010). The Economist Intelligence Unit (2012) reports, "Although they may not be able to quantify it, governments in most countries recognize a link between the knowledge and the skills with which young people enter the workforce and long-term economic competitiveness" (p. 6). Spring (2014), suggests colleges and universities are "already in the best position to benefit from, and contribute to, the increasing exchange of knowledge" (p. 93). The global knowledge-driven economy will require advanced education, colleges and universities face a move from more formal traditional roles of working for the public good to redefining their institutional mission to include innovation, entrepreneurship, and marketing (Guri-Rosenblit, 2010). The digital economy is a "third wave of capitalism that will transform many aspects of the global marketplace" (Oxford Economics, 2011, p. 2) and the digital economy offers "huge opportunities for...companies that can adapt" (p. 3). Digital technologies are creating greater access to education, new markets for distribution, and expanded income opportunities for higher education institutions (Bano \& Taylor, 2015).

\section{Globalization for Students}

In today's evolving, global educational marketplace students are accustomed to instant access, any time, any place (Jones \& Skinner, 2014). Ubiquitous anytime, anywhere learning is attractive to adult learners who balance both home and career (Barton \& Ryan, 2014; Sife, Lwoga, \& Sanga, 2007). With technological innovations creating broader access to higher education, there are increasing opportunities for postsecondary institutions to expand revenue sources by selling knowledge (Altbach, 2004, 2015; Geiger, 2004; Slaughter \& Rhoades, 2004). Accordingly, higher education institutions are positioning themselves in the national and international market as entrepreneurial models (Altbach \& Knight, 2007; Altbach \& Reisberg, 2015; Altbach, Reisberg, \& Rumbley, 2009; Barnett, 2011; Etzkowitz \& Leydesdorff, 1998; Lane, Lemoine, Tinney, \& Richardson, 2014; Marginson, 2006; Shofer \& Meyer, 2006; Teichler, 2006).

Change is necessary for postsecondary education institutions to remain viable (Khan, 2015; Levin, 2011). Halavais (2000) suggests survival for institutions necessitates adaptation and a move away from traditional educational paradigms. The physical university is now a combination multi-dimensional education model: physical and online, or online (Tapscott \& Williams, 2010). Universities are using technology as one of the primary means for initiating and maintaining contact with a diverse and changing student population looking for anywhere, anytime learning (Bates, 2010; Blin \& Munro, 2008; Dietz \& Bozeman, 2005; Guri-Rosenblit, Sebhova, \& Teichler, 2007; Hannan, 2005).

Globalization and technological changes, while presenting tremendous challenges, bring vast opportunities. Globalization, for example, vastly expands the pool of potential customers for products and services. Niche talents that used to be of only interest to a small fraction of people may not be of much value locally because the total population is small in a given community. In the globalized world, the potential customers could be seven billion people. Even a small fraction of seven billion can be significant. Additionally, talents that may be of little value in a given location can be very valuable in another. Globalization and technology today enable products and services to reach almost any corner of the world. (Zhoa, 2012, pp. 44-45)

Thus, in the push to be globally competitive, every country, large or small, is tackling educational reform (Greenhow, 2011; Levine, 2011).

\section{Education As a Public Good}

Historically education has been regarded as public good producing enormous benefits not only to individuals but also the whole society (Kauppinen, 2014). In the case of higher education too, not only educationists, but also other social scientists and thinkers including economists, have recognized the public good nature: higher education constitutes a public good, and it produces public goods, benefiting simultaneously the individuals and the larger society (Gradstein \& Justman, 2002). Education, as a public good and as a commodity, serves two agendas: the spread of benefits from an educated citizenry cannot be restricted to a small population, nor is the quantum of benefits received by some affected by the level of benefits others receive (Kaul, Conceicao, le Goulven, \& Mendoza, 2003; Kaul, Grunberg, \& Sten, 1999). In addition, higher education institutions have multiple objectives, not just economic. They produce multiple, varied types of outputs, some tangible and many not. Because of these special features, public goods like higher education cannot be provided by countries in a manner that satisfies social demand (Shofer \& Meyer, 2006).

The public good nature of higher education is well understood in reference to the traditional functions of higher 
education and the social benefits provided (Newman, Courturier, \& Scurry, 2004). However, higher education is facing two severe impediments to both growth and sustainability. First, governments around the world have steadily minimized their support for public higher education, and expenses have increased constantly over the last decade (Stiglitz, 1999). Second, governments are increasing pressure on universities to demonstrate the value of their degrees in short-term, quantitative and market-related measures (Naidoo, 2007). Most universities are now forced to adopt a unique form of corporate restructuring creating a corrosive influence for commoditizing education related to the standardization of degree production in institutions asked to make a profit from large numbers of student-consumers (Ball, Dworkin, \& Vryonides, 2010). In a time when ecological, social, cultural and economic challenges require innovative solutions and new concepts, higher education must deliver both creativity for sustainability and resilience for accountability (Balan, 2015). This dilemma forces universities to pursue both excellence and equity in a climate of accountability and competition (Teichler, 2004, 2006).

In contrast to this economic research recent writings on the public good in higher education by sociologists, political scientists, and educationists have been largely critical (Brown, 2008; Carnoy, Froumin, Loyalka, \& Tilak, 2014; Marginson, 2007; Rizvi \& Lingard, 2010; Theodore, 2014; Tilak, 2008). These researchers suggest the policy reforms of the last several decades, which have introduced greater "privatization" and market competition into higher education systems, have also lessened the "public goods" provided by higher education institutions and are compromising academic activity within universities (Brown, 2008; Burch, 2006). The recent literature on the public good in higher education has raised some important and challenging questions regarding the potential impacts of national policies on the academic integrity of universities (Brown, Lauder, \& Ashton, 2008). Although international education is seen as a potential to increase access to higher education, deep concerns have been raised about the equity of access (Brooks, 2005).

\section{Higher Education as an International Commodity}

Education is a significant instrument for permitting enhanced social participation of people and demonstrating the function of democracy and a learning society (Apple, 2006). This type of qualitative outcome is difficult to measure (Broadbent, 2007). However, the movement or trade in goods and services, including educational services, across international borders is viewed as the crucial economic outcome of globalization (Ball, Dworkin, \& Vryonides, 2010; Khan, 2015). Important international decision makers, policy-makers and politicians consider higher education to be a tradable commodity as well as a social service and often a privilege (Tomasevski, 2005, 2006).

Economic considerations related to international competitiveness have become a significant driving strength behind the internationalization of learning (Adhikari, 2010). Along with the movement of goods and general services, the movement of educational services and products has improved significantly in the last decade (Bloom, 2005). Education is increasingly seen not only as an export commodity, but also as a key national brand for a nation's knowledge proficiency (Bano \& Taylor, 2015). Knowledge institutions, whether private or public, are regarded as significant stakeholders in a country's global and local competitiveness (Chan \& Dimmock, 2008; Tjeldvoll, 2010).

As learning becomes increasingly borderless, higher education policy is likely to rank increasingly high on national agendas (Youngs, 2013). Developing countries view increasing higher education participation as crucial to their transition to developed country standing (Amaral, Meek, \& Larsen, 2003). The argument that higher education is a major driver of economic competitiveness in an increasingly knowledge-driven global economy is now widely accepted (Breenan, 2008).

\section{The Influence of Technology in Higher Education}

Technology has ushered in a new era in higher education, particularly in the international market (Goldin \& Katz, 2008). Understanding new information and communication technologies is essential for administrators of higher education systems from both a local and global perspective (Zhao, Alexander, Perreault, Waldman, \& Truell, 2009). To open many global markets, higher education institutions are more important than ever as media for a wide range of relationships and continuous flow of resources (Zhu, 2015). Technology is transforming higher education by providing a global focus, thereby intensifying the global interconnectedness (Culp, Honey, \& Mandinach, 2005). Technology has now become central to the global changes: reshaping social, economic and cultural life. Technology has not created international universities, but all are impacted by the conceptual and realistic impact of globalism, both in terms of education (instruction) and resources (students) (Devi, Bimol, \& Saikia, 2014).

The world now experiences the first world-wide systems of communications, information, knowledge and 
culture that have ever served to bind the world together and create a global state (Golden \& Katz, 2008). However, globalization is not a universal phenomenon, and can vary according to management, policy, and government (Fahmy, 2004; Monteiro \& Sharma, 2014; Sharma, 2014). Some elements are similar, if not consistent. Continuously extending networks based on travel, mobile phones, broad-band Internet and other information and communications technologies (ICTs), are creating new forms of inter-subjective human association, of unprecedented scale and flexibility, spanning cities and nations with varied cultures and levels of economic development (Zajda, 2015). Commonality also enables the complex data transfers essential to knowledge-intensive production (Youngs, 2013).

During the past decade, technical innovations have altered the skills and knowledge needed to succeed in the workplace and society (Garrison \& Akyol, 2009). Preparing technically educated and skilled individuals is of great economic importance to the United States and other countries and requires significant attention from educators and employers. Education is the one area that influences an individual from early childhood through adult life (Lemoine \& Richardson, 2013). Higher education institutions around the world provide students with the knowledge and skills necessary to function in society (LeBlanc, 2012). Now that society has assumed a global focus, supported by technology, higher education institutions are asked to offer the highest quality education, especially technology literacy, to a widely diverse audience at a cost that can be supported by society (Marshall, 2010). Technology should not be an end for education; it should be the means to achieve the end (Kirschner, 2012).

\section{Economic and Financial Considerations of Globalization and Higher Education}

Modern society has moved rapidly toward globalization. Most of the elements of society, particularly higher education, are struggling with globalization across cultures and around the world (Morley, Marginson, \& Blackmore, 2014). The globalization of education places a new emphasis on both the content and process of education coupled with global ramifications for delivery. Consequently, higher education is increasingly viewed as a major engine of economic development (Lane, Kehr, \& Richardson, 2009).

Globally, universities are being forced to reconsider their missions and goals (Taylor \& Morphew, 2015). Society no longer grants privilege and financial commitment to higher education because tax dollars are scarce (Zott, Amit, \& Massa, 2011). Many perceive that those receiving the most from higher education institutions should pay for the privilege, dramatically increasing tuition and fees (McClung \& Wernerm, 2008). Many perceive higher education to be very costly, yet it is also widely seen as highly beneficial to the country's economy (Shin $\&$ Kehn, 2013). For many in underserved regions of the world, higher education has become necessary for social mobility and economic success although cost remains an enormous barrier (Staley \& Trinkle, 2011). As a result, higher education has also experienced a new demand for financial accountability (Broadbent, 2007). Across the world, colleges and universities are experiencing dwindling public dollars coupled with the dynamic increase of students (Duderstadt, 2002; Luke, 2005; Weber \& Duderstadt, 2012). In financial terms, this has become an unsustainable model, with increasing demands regarding healthcare, public safety, and quality of life issues taking priority (Krucken, 2014).

In addition, demographic changes also pose direct, long-term challenges to universities. An aging population shapes spending priorities for many in the global market. Many countries are being forced to compete for talent with each other, striving not only to keep their own students at home, but also to recruit and retain talented students and workers from other countries (Deumert, Marginson, Nyland, Ramia, \& Sawir, 2005; Morris, 2009). In addition, an ever-expanding diverse society, including growing minority populations and high rates of immigration, assures that colleges and universities will need additional resources to meet the needs of these diverse students (Apple, 2011; Shin \& Kehm, 2013).

Colleges and universities are important incubators for finance, talent and innovation (Vaira, 2004). They attract top students, resourceful faculty, prestigious research grants, business and jobs and are a huge revenue generator when used effectively and efficiently (Mok, 2015). They generate revenue and resources and are uniquely positioned to provide leadership for future innovation, development and change (Lane, Kehr, \& Richardson, 2009).

\section{Concluding Thoughts}

Higher education leadership needs to develop new organizational structures and systems that will promote and encourage quality learning and the ability to assess the impact of the teaching. Governments across the world have steadily minimized their support for public higher education, and costs associated with gaining a degree have increased constantly over the last decade. Most universities are forced to adopt a restructuring model for commoditizing education to make a profit from large numbers of students. The road ahead for higher education 
is filled with challenges, risks and uncertainties that begin with education being valued as more than a simple commodity: education becomes a public good. Higher education is increasingly viewed as a major instrument of economic development. To hold universities accountable despite limited governmental budgets, many nations have adopted performance-based university research funding strategies for targeted programs. Citizens and bureaucrats in many countries are asking more frequently what tangible benefits the society is receiving for the tax revenues being spent on higher education.

Historically, education was viewed as a basic human need and a key factor in social and economic development. Investment in education was perceived to raise the well-being of individuals while elevating their 'human capital' and economic capacity. Education was also viewed as a means of reducing inequality and a venue for social development. The capacities for countries to adopt, disseminate, and maximize rapid technological and educational improvements were reliant on adequate systems of education. However, many politicians view education as a commodity and not a service. Certain influential decision makers considered higher education to be a tradable commodity as well as a social service. Although education was increasingly seen as an export commodity, educational professionals perceived higher education as a public good and a tradable commodity. Many researchers assume that globalization and internationalism exploited higher education so that it was seen primarily as a private good subject to national and international markets. The road ahead for higher education is filled with challenges, risks and uncertainties that began with education being valued as more than a simple commodity or a public good. The marketing and selling of education at the international level has had both positive and negative effects on the future of global education because stakeholders are increasingly asking whether students are learning and whether institutions are providing a quality of service that justifies their cost (Newmanm \& Jahdi, 2009).

Higher education is implicated in all these economic and global changes. Education is a key element in the formation of an international environment that is swept up in global marketization. Consequently, the main student growth in this global market is in globally mobile degrees in business studies and computing. Is higher education a commodity to be bought and sold or is it a service in the creation of economic globalism? Regardless, higher education is essential to the creation, exchange and implementation of knowledge in a global marketplace with many unintended consequences, like accountability. Globalization and accountability create an atmosphere in higher education where knowledge and information are more vastly prized and more highly globalized than are localized economic concerns. The best example is the internet which supports high economic volume, makes a larger contribution to the distribution of knowledge and information, but must be viewed through the lens of both technology and accountability.

\section{References}

Adeoye, B., \& Wentling, R. M. (2007). The relationship between national culture and usability of an e-learning system. International Journal on E-Learning, 6(1), 119-146.

Adhikari, D. R. (2010). Knowledge management in academic institutions. International Journal of Educational Management, 24(2), 94-104. https://doi.org/10.1108/09513541011020918

Akiba, M., LeTendre, G., \& Scribner, J. (2007). Teacher quality, opportunity gap, and national achievement in countries. Educational Researcher, 36(7), 369-387. https://doi.org/10.3102/0013189X07308739

Altbach, P. G. (2004). Globalization and the university: Myths and realities in an unequal world. Tertiary Education and Management, 10(1), 3-25. https://doi.org/10.1080/13583883.2004.9967114

Altbach, P. G. (2014). India's higher education challenges. Asia Pacific Education Review, 15(4), 503-510. https://doi.org/10.1007/s12564-014-9335-8

Altbach, P. G. (2015). Higher education and the WTO: Globalization run amok. International Higher Education, 23(1), 2-4. https://doi.org/10.6017/ihe.2001.23.6593

Altbach, P. G., \& Knight, J. (2007). The internationalization of higher education: Motivations and realities. Journal of Studies in International Education, 11(3-4), 274-290. https://doi.org/10.1177/1028315307303542

Altbach, P. G., Reisberg, L., \& Rumbley, L. E. (2009). Trends in global higher education; Tracking an academic revolution. Paris: UNESCO.

Altbach, P., \& Reisberg, L. (2015). The pursuit of international students in a commercialized world. International Higher Education, 73, 2-4. https://doi.org/10.6017/ihe.2013.73.6115

Amaral, A., Meek, V. L., \& Larsen, I. M. (2003). The higher education managerial revolution? Dordrecht, The Netherlands: Kluwer Academic Publishers. https://doi.org/10.1007/978-94-010-0072-7 
Apple, M. (2006). Educating the "right” way: Markets, standards, God, and inequality. New York: Taylor \& Francis.

Apple, M. W. (2011). Democratic education in neoliberal and neoconservative times. International Studies in Sociology of Education, 21(1), 21-31. https://doi.org/10.1080/09620214.2011.543850

Baker, D., \& LeTendre, G. (2005). National differences, Global similarities: World culture and the future of schooling. Stanford, CA: Stanford University Press.

Balán, J. (2015). The Crisis of the Public Mission in Higher Education. International Higher Education, 80, 4-5. https://doi.org/10.6017/ihe.2015.80.6130

Ball, S. J. (2010). Privatising education, privatizing education policy, privatizing educational research: Network governance and the "competition state". Journal of Education Policy, 24(1), 83-99. https://doi.org/10.1080/02680930802419474

Ball, S. J. (2012). The reluctant state and the beginning of the end of state education. Journal of Educational Administration and History, 44(2), 89-103. https://doi.org/10.1080/00220620.2012.658764

Ball, S. J., Dworkin, A. G., \& Vryonides, M. (2010). Globalization and education: Introduction. Current Sociology, 58(4), 523-529. https://doi.org/10.1177/0011392110367987

Bano, S., \& Taylor, J. (2015). Universities and the knowledge-based economy: Perceptions from a developing

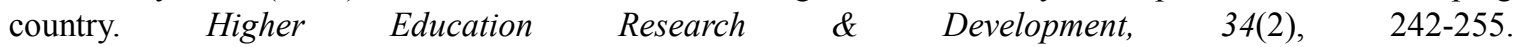
https://doi.org/10.1080/07294360.2014.956696

Barnett, R. (2011). The marketised university: Defending the indefensible. In M. Molesworth, R. Scullion, \& E. Nixon (Eds), The Marketisation of Higher Education and the Student as Consumer (pp. 39-51). London: Routledge.

Barton, G., \& Ryan, M. (2014). Multimodal approaches to reflective teaching and assessment in higher education. Higher Education Research \& Development, 33(3), 409-424. https://doi.org/10.1080/07294360.2013.841650

Bashir, S. (2007). Trends in international trade in higher education: Implications and options for developing countries. Washington, DC: World Bank.

Bates, T. (2010). New challenges for universities: Why they must change. In U. D. Ehlers, \& D. Schneckenberg (Eds.), Changing Cultures in Higher Education (pp. 15-25). Berlin: Springer. https://doi.org/10.1007/978-3-642-03582-1_2

Beech, J. (2011). Global panaceas, local realities: International agencies and the future of education. Frankfurt Am Main: Peter Lang.

Bement, A. L. Cyberinfrastructure: The second revolution. Chronicle of Higher Education, 53(18), B. 5.

Bergh, A., \& Nilsson, T. (2010). Do liberalization and globalization increase income inequality? European Journal of Political Economy, 26, 488-505. https://doi.org/10.1016/j.ejpoleco.2010.03.002

Bickerstaff, S., \& Cormier, M. S. (2015). Examining faculty questions to facilitate instructional improvement in $\begin{array}{lllll}\text { higher education. Studies in Educational Evaluation, } 46, & \text { 74-80. }\end{array}$ https://doi.org/10.1016/j.stueduc.2014.11.004

Bleiklie, I. (2005). Organizing higher education in a knowledge society. Higher Education, 49(1), 31-59. https://doi.org/10.1007/s10734-004-2913-7

Blin, F., \& Munro, M. (2008). Why hasn't technology disrupted academics' teaching practices? Understanding resistance to change through the lens of activity theory. Computers and Education, 50, 475-490. https://doi.org/10.1016/j.compedu.2007.09.017

Bloom, D. (2005). Raising the pressure: Globalization and the need for higher education reform. In G. Jones, P. McCarney, \& M. Skolnik (Eds.), Creating knowledge: Strengthening nations: The changing role of higher education. Toronto: University of Toronto Press. https://doi.org/10.3138/9781442673564-004

Bok, D. (2013). Higher education in America. Princeton, NJ: Princeton University Press.

Brennan, J. (2008). Higher Education and Social Change. Higher Education, 56(3), 381-393. https://doi.org/10.1007/s10734-008-9126-4

Broadbent, J. (2007). If you can't measure it, how can you manage it? Management and governance in higher 
educational institutions. Public Money and Management, 27(3), 193-198. https://doi.org/10.1111/j.1467-9302.2007.00579.x

Brooks, R. (2005). Measuring university quality. The Review of Higher Education, 29(1), 1-21. https://doi.org/10.1353/rhe.2005.0061

Brown, P., Lauder, H., \& Ashton, D. (2008). Education, globalisation and the future of the knowledge economy. European Educational Research Journal, 7(2), 131-156. https://doi.org/10.2304/eerj.2008.7.2.131

Brown, R. (2008). Higher education and the market. Perspectives: Policy and Practice in Higher Education, 12(3), 73-83. https://doi.org/10.1080/13603100802181125

Burch, P. E. (2006). The new educational privatization: Educational contracting and high stakes accountability. Teachers College Record, 108, 2582-2610. https://doi.org/10.1111/j.1467-9620.2006.00797.x

Caminada, K., \& Martin, M. C. (2012). Differences in anti-poverty approaches in Europe and the United States: A cross-Atlantic descriptive policy analysis. Poverty \& Public Policy, 3(2), 1-15.

Carnoy, M. (2014). Globalization, educational change, and the national state. In Globalization and education: Integration and contestation across cultures (pp. 21-38). Lanham, MD: Rowman \& Littlefield.

Carnoy, M., Froumin, I., Loyalka, P. K., \& Tila, J. B. (2014). The concept of public goods, the state, and higher education finance: a view from the BRICs. Higher Education, 68(3), 359-378. https://doi.org/10.1007/s10734-014-9717-1

Castle, S., \& McGuire, C. (2010). An analysis of student self-assessment of online, blended, and face-to-face learning environments: Implications for sustainable education delivery. International Education Studies, 3(3), 36-40. https://doi.org/10.5539/ies.v3n3p36

Chan, W. W. Y., \& Dimmock, C. (2008). The internationalization of universities: Globalist, internationalist and translocalist models. Journal of Research in International Education, 7, 184-204. https://doi.org/10.1177/1475240908091304

Choudaha, R., Chang, L., \& Kono, Y. (2013). International student mobility trends 2013: Towards responsive recruitment strategies. World Education News \& Reviews, 26(2), 3-21.

Coley, R. J., \& Baker, B. (2013). Poverty and education: Finding the way forward. Princeton, NJ: Educational Testing Service.

Culp, K. M., Honey, M., \& Mandinach, E. (2005). A retrospective on twenty years of education technology policy. Journal of Educational Computing Research, 32(3), 279-307. https://doi.org/10.2190/7W71-QVT2-PAP2-UDX7

Demange, G., Fenge, R., \& Uebelmesser, S. (2014). Financing higher education in a mobile world. Journal of Public Economic Theory, 16(3), 343-371. https://doi.org/10.1111/jpet.12064

Deumert, A., S. Marginson, C. Nyland, G. Ramia, \& E. Sawir. (2005). Global migration and social protection: The social and economic security of foreign students in Australia. Global Social Policy, 5(3), 329-352. https://doi.org/10.1177/1468018105057415

Devi, L. P., Bimol, S., \& Saikia, M. (2014). Information and communication technology influence in education system. International Journal of Information Technology \& Computer Sciences Perspectives, 3(4), 1265.

Dietz, J. S., \& Bozeman, B. (2005). Academic careers, patents, and productivity: Industry experience as scientific and technical human capital. Research Policy, 34(3), 349-367. https://doi.org/10.1016/j.respol.2005.01.008

DiGioacchino, D., \& Sabani, L. (2009.) Education policy and inequality: A political economy approach. European Journal of Political Economy, 25, 463-478. https://doi.org/10.1016/j.ejpoleco.2009.06.002

Douglas, J. A., King, C. J., \& Feller, I. (Eds.) (2009). Globalization's muse. In Universities and higher education systems in a changing world. Berkeley, CA: University of California Berkeley Public Policy Press.

Duderstadt, J. J. (2001, May). The future of the university in the digital age. Presented at The Glion III Conference, Glion, Switzerland.

Duderstadt, J. J. (2002, October). The future of higher education in the knowledge-driven, global economy of the 21st century. Presented at Creating Knowledge, Strengthening Nations: The Changing Role of Higher Education A Symposium in Celebration of the 175th Anniversary of the University of Toronto Charter, Toronto, Canada. 
Economist Intelligence Unit. (2012). The learning curve: Lessons in country performance in education. In 2012 report. London: Economist Intelligence Unit and Pearson.

Enders, J. (2004). Higher education, internationalization, and the nation-state: Recent developments and challenges for governance theory. Higher Education, 47(3), 361-382. https://doi.org/10.1023/B:HIGH.0000016461.98676.30

Etzkowitz, H., \& Leydesdorff, L. (1998). The endless transition: A "triple helix" ofuniversity-industry-government relations, introduction to a theme issue. Minerva, 36, 203-208. https://doi.org/10.1023/A:1004348123030

Fahmy, M. (2004). Thinking about technology effects on higher education. The Journal of Technology Studies, 30(1), 53-58. https://doi.org/10.21061/jots.v30i1.a.9

Fallis, G. (2007). Multiversities, ideas and democracy. Toronto: University of Toronto Press. https://doi.org/10.3138/9781442684638

Feigenbaum, A., \& Iqani, M. (2015). Quality after the cuts? Higher education practitioners' accounts of systemic challenges to teaching quality in times of 'austerity'. Journal of Further and Higher Education, 39(1), 46-66. https://doi.org/10.1080/0309877X.2013.778961

Ferreira, N. S., Haddad, M. E., \& Faria, A. A. (2014). Educational technology and educational management in the higher education: New ways of forming professionals. Open Journal of Social Sciences, 2(2), 7. https://doi.org/10.4236/jss.2014.22002

Frank, D., \& Gabler, J. (2007). Reconstructing the university: Global changes in the academic core over the 20th Century. Stanford, CA: Stanford University Press.

Garrison, D. R., \& Akyol, Z. (2009). Role on instructional technology in the transformation of higher education. Journal of Computing in Higher Education, 21(1), 19-30. https://doi.org/10.1007/s12528-009-9014-7

Geenough, W. T., McConnaughay, P. J., \& Kesan, J. P. (2007). Defining values for research and technology: The university's changing role. Lanham, MD: Rowman and Littlefield.

Geiger, R. L. (2004). Knowledge and money: Research universities and the paradox of the marketplace. Stanford, CA: Stanford University Press.

Giroux, H. A. (2009). Democracy's nemesis: The rise of the corporate university. Cultural Studies and Critical Methodologies, 9(5), 669-695. https://doi.org/10.1177/1532708609341169

Goldin, C., \& Katz, L. F. (2008). The race between education and technology. Cambridge, MA: Belknap Press of Harvard University Press.

Goldstein, H. (2004). Education for all: The globalization of learning targets. Comparative Education, 40(1), 7-14. https://doi.org/10.1080/0305006042000184854

Gradstein, M., \& Justman, M. (2002). Education, social cohesion and economic growth. American Economic Review, 92(4), 1192-1204. https://doi.org/10.1257/00028280260344722

Graves, W. H. (2010). Waste not the learning productivity crisis: Transforming education opportunity into educational assurance. Educause Review, 45(1), 1-74.

Greenhow, C. (2011). Online social networks and learning. On the Horizon, 19(1), 4-12. https://doi.org/10.1108/10748121111107663

Guile, D. (2001). Education and the economy: Rethinking the question of learning for the 'knowledge' era. Futures, 33(6), 469-482. https://doi.org/10.1016/S0016-3287(00)00091-4

Guri-Rosenblit, S. (2009). Digital technologies in higher education: Sweeping expectations and actual effects. New York: Nova Science Publishers.

Guri-Rosenblit, S. (2010). Digital technologies in higher education: Sweeping expectations and actual effects. New York, NY: Nova Science.

Guri-Rosenblit, S., Sebkova, H., \& Teichler, U. (2007). Massification and diversity of higher education systems: Interplay of complex dimensions. Higher Education Policy, 20(4), 373-389. https://doi.org/10.1057/palgrave.hep.8300158

Halavais, A. (2000). National borders on the world wide web. New Media \& Society, 2(1), 7-28. https://doi.org/10.1177/14614440022225689 
Hannan, A. (2005). Innovating in higher education: contexts for change in learning technology. British Journal of Educational Technology, 36(6), 975-985. https://doi.org/10.1111/j.1467-8535.2005.00568.x

Haskins, R. (2008). Education and economic mobility. In J. Isaacs, I. Sawhill, \& R. Haskins (Eds.), Getting ahead or losing ground: Economic mobility in America (pp. 91-104). Washington, DC: Economic Mobility Project, an Initiative of the Pew Charitable Trusts.

Haskins, R., Holzer, H., \& Lerman, R. (2009). Promoting economic mobility by increasing post-secondary education. Washington, DC: Economic Mobility Project, an Initiative of the Pew Charitable Trusts.

Healey, N. M. (2008). Is higher education really "internationalizing"? Higher Education, 55(3), 333-355. https://doi.org/10.1007/s10734-007-9058-4

Heaney, L. (2009). NAFSA's guide to international student recruitment. Washington, DC: NAFSA, Association of International Educators.

Hekkert, M. P., \& Negro, S. O. (2009). Functions of innovation systems as a framework to understand sustainable technological change: Empirical evidence for earlier claims. Technological Forecasting and Social Change, 76(4), 584-594. https://doi.org/10.1016/j.techfore.2008.04.013

Hogan, J. (2015). Reshaping the university: the rise of the regulated market in higher education. Perspectives: Policy and Practice in Higher Education, 19(1), 33-34. https://doi.org/10.1080/13603108.2014.963728

Johnstone, D. B. (2004). The economics and politics of cost sharing in higher education: Comparative $\begin{array}{llll}\text { perspectives. Economics of Education } & \text { Review, 23(4), }\end{array}$ https://doi.org/10.1016/j.econedurev.2003.09.004

Jones, P., \& Skinner, H. (2014). E-learning globalization: the impact of e-learning-what difference has it made? Education + Training, 56(2-3). https://doi.org/10.1108/ET-11-2013-0128

Judson, K. M., \& Taylor, S. A. (2014). Moving from marketization to marketing of higher education: The co-creation of value in higher education. Higher Education Studies, 4(1), 51-67. https://doi.org/10.5539/hes.v4n1p51

Kaiser, F., Maassen, P., Meek, L., van Vught, F., de Weert, E., \& Goedegebuure, L. (Eds.) (2014). Higher education policy: An international comparative perspective. Elsevier.

Kaul, I., Grunberg, I., \& Stern, M. (Eds.) (1999). Global Public Goods: International Cooperation in the 21st Century. New York: Oxford University Press. https://doi.org/10.1093/0195130529.001.0001

Kaul, I., P., Conceicao, K. le Goulven, \& R. Mendoza (Eds.) (2003). Providing Global Public Goods: Managing Globalisation. New York: Oxford University Press. https://doi.org/10.1093/0195157400.001.0001

Kauppi, N., \& Errkla, T. (2011). The struggle over global higher education: Actors, institutions, and practices. International Political Sociology, 5, 314-326. https://doi.org/10.1111/j.1749-5687.2011.00136.x

Kauppinen, I. (2014). Different meanings of 'knowledge as commodity' in the context of higher education. Critical Sociology, 40(3), 393-409. https://doi.org/10.1177/0896920512471218

Khan, A. U. (2015). What globalization means for the education sector: How do we cater to emerging needs? Emerging Economy Studies, 1(1), 96-107. https://doi.org/10.1177/2394901514562303

Kirschner, A. (2012, April 8). Innovations in higher education? Hah! College leaders need to move beyond talking about transformation before it's too late. Chronicle of Higher Ed Online. Retrieved from http://chronicle.com/article/Innovations-in-Higher/131424/

Krücken, G. (2014). Higher education reforms and unintended consequences: a research agenda. Studies in Higher Education, 39(8), 1439-1450. https://doi.org/10.1080/03075079.2014.949539

Lane, K. E., Kehr, G. R., \& Richardson, M. D. (2009, January). The paradox of marketing productivity in higher education. A paper presented at the annual meeting of the International Academy of Educational Leaders in Vancouver, Canada.

Lane, K. E., Lemoine, P., Tinney, T. M., \& Richardson, M. D. (2014). Modify and adapt: Global higher education in a changing economy. International Journal of Innovation in the Digital Economy (IJIDE), 5(2), 24-36. https://doi.org/10.4018/ijide.2014040103

LeBlanc, P. (2012, August). Making sense of disruptive technologies and higher education: A theory of change, the growth of online programs, and the next generation of delivery models. Paper presented prepared for the American Enterprise Institute Conference. 
Lemoine, P., \& Richardson, M. D. (2013). Cyberlearning: The impact on instruction in higher education. Researcher: An Interdisciplinary Journal, 26(3).

Levin, B. (2011). Mobilizing research knowledge in education. London Review of Education, 9(1), 15-26. https://doi.org/10.1080/14748460.2011.550431

Lovett, C. M. (2013). The global contexts of higher education. Change: The Magazine of Higher Learning, 45(1), 73-78. https://doi.org/10.1080/00091383.2013.749169

Lub, A., van der Wende, M. C., \& Huisman, J. (2005). On cooperation and competition: A comparative analysis of national policies for internationalization of higher education in seven Western European countries. Journal of Studies in Higher Education, 9(2), 147-163.

Luke C. (2005). Capital and knowledge flows: Global higher education markets. Asia Pacific Journal of Education, 25(2), 159-174. https://doi.org/10.1080/02188790500337940

Marginson, S. (2006). Dynamics of national and global competition in higher education. Higher Education, 52(1), 1-39. https://doi.org/10.1007/s10734-004-7649-x

Marginson, S. (2007). Prospects of higher education: Globalization, market competition, public goods and the future of the university. Rotterdam: The Netherlands: Sense Publishers.

Marshall, S. (2010). Change, technology and higher education: Are universities capable of organizational change? Research in Learning Technology, 18(3), 179-192. https://doi.org/10.1080/09687769.2010.529107

McClung, G. W., \& Wernerm, M. W. (2008). A market/value based approach to satisfy stakeholders of higher education. Journal of Marketing for Higher Education, 18(1), 102-123. https://doi.org/10.1080/08841240802100345

McMahon, W. W. (2009). Higher learning, greater good: The private and social benefits of higher education. Baltimore, MD: The Johns Hopkins University Press.

Miller, B. (2010). Skills for sale: What is being commodified in higher education? Journal of Further and Higher Education, 34(2), 199-206. https://doi.org/10.1080/03098771003695460

Mohrmana, K., Mab, W., \& Bakerc, D. (2008). The research university in transition: The emerging global model. Higher Education Policy, 21, 5-27. https://doi.org/10.1057/palgrave.hep.8300175

Mok, K. H. (2015). Higher education transformations for global competitiveness: Policy responses, social consequences and impact on the academic profession in Asia. Higher Education Policy, 28(1), 1-15. https://doi.org/10.1057/hep.2014.27

Monteiro, S., \& Sharma, R. (2014). Global interdependence and cultural hybridization: The stimulus for social change. Global Studies Journal, 6(3). https://doi.org/10.18848/1835-4432/CGP/v06i03/40898

Morley, L., Marginson, S., \& Blackmore, J. (2014). Education and neoliberal globalization. British Journal of Sociology of Education, 35(3), 457-468. https://doi.org/10.1080/01425692.2014.893072

Morris, L. V. (2009). Leadership and the future of higher education. Innovative Higher Education, 35(1), 1-2. https://doi.org/10.1007/s10755-009-9129-9

Naidoo, R. (2007). Higher education as a global commodity: The perils and promises for developing countries. London, England: The Observatory on Borderless Higher Education.

Newman, F., Courturier, L., \& Scurry, J. (2004). The future of higher education: Rhetoric, reality and the risk of the market. San Francisco, CA: Jossey-Bass.

Newmanm, S., \& Jahdi, K. (2009). Marketisation of education: Marketing, rhetoric and reality. Journal of Further and Higher Education, 33(1), 1-11. https://doi.org/10.1080/03098770802638226

Olaniran, B. A., \& Agnello, M. F. (2008). Globalization, educational hegemony, and higher education. Multicultural Education \& Technology Journal, 2(2), 68-86. https://doi.org/10.1108/17504970810883351

Ornstein, A., \& Eng, N. (2015). 21st Century Excellence in Education: Introduction. Society, 52(2), 121. https://doi.org/10.1007/s12115-015-9871-9

Oxford Economics (2011, June). The new digital economy: How it will transform business. Oxford, United Kingdom: Author. Retrieved from http://www.pwc.com/gx/en/technology/publications/assets/the-new-digital-economy.pdf

Palfreyman, D. (2010). The conditions for admission: Access, equity, and the social contract of public 
universities. Perspectives: Policy and Practice in Higher Education, 14(2), 63-64. https://doi.org/10.1080/13603100902808668

Rizvi, F., \& Lingard, B. (2010). Globalizing education policy. New York, NY: Routledge.

Rogers, P. L. (2001). Traditions to transformations: The forced evolution of higher education. Educational Technology Review, 9(1), 47-60.

Secundo, G., Margherita, A., Elia, G., \& Passiante, G. (2010). Intangible assets in higher education and research: Mission, performance or both? Journal of Intellectual Capital, 11(2), 140-157. https://doi.org/10.1108/14691931011039651

Sharma, N. K. (2014). Globalization and its Impact on the Third World Economy. Crossing the Border: International Journal of Interdisciplinary Studies, 1(1), 21-28. https://doi.org/10.3126/ctbijis.v1i1.10465

Shin, J. C., \& Kehn, B. M. (Eds.) (2013). Institutionalization of world-class universities in global competition. Heidelberg: Springer. https://doi.org/10.1007/978-94-007-4975-7

Shofer, E., \& Meyer, J. (2006). The world-wide expansion of higher education in the twentieth century. American Sociological Review, 70(6), 898-920. https://doi.org/10.1177/000312240507000602

Sife, A. S., Lwoga, E., \& Sanga, C. (2007). New technologies for teaching and learning: Challenges for higher learning institutions in developing countries. International Journal of Education and Development Using ICT, 3(2).

Slaughter, S., \& Rhoades, G. (2004). Academic capitalism and the new economy: Markets, state and higher education. Baltimore, MD: Johns Hopkins University Press.

Spring, J. (2008). Research on globalization and education. Review of Educational Research, 78(2), 330-363. https://doi.org/10.3102/0034654308317846

Spring, J. (2014). Globalization of education: An introduction. Routledge.

Stainer, D. L. J., \& Stainer, A. (2011). Productivity science and sustainability-A value-driven synthesis. International Journal of Management and Decision Making, 11(3-4), 197-216. https://doi.org/10.1504/IJMDM.2011.040699

Staley, D. J., \& Trinkle, D. A. (2011, January/February). The changing landscape of higher education. EDUCAUSE eView, 46(1), 16-32.

Stiglitz, J. (1999). Knowledge as a Global Public Good. In I. Kaul, I. Grunberg, \& M. Stern (Eds.), Global Public Goods: International Cooperation in the 21st Century (pp. 308-325). New York: Oxford University Press. https://doi.org/10.1093/0195130529.003.0015

Stromquist, N. P. (2002). Education in a globalized world: the connectivity of economic power, technology, and knowledge. Lanham, MD: Rowman and Littlefield.

Stromquist, N. P., \& Monkman, K. (Eds.) (2014). Globalization and education: Integration and contestation across cultures. New York, NY: R\&L Education.

Tannock, S. (2013). When the demand for educational equality stops at the border: Wealthy students, international students and the restructuring of higher education in the UK. Journal of Education Policy, 28(4), 449-464. https://doi.org/10.1080/02680939.2013.764577

Tapscott, D., \& Williams, W. D. (2010). Innovating the 21st-Century university: It's time! Educause Review, 45(1), 16-29.

Taylor, B. J., \& Morphew, C. C. (2015). Trends in cost-sharing in the US and potential international implications. Higher Education Policy, 28(2), 129-149. https://doi.org/10.1057/hep.2013.39

Teichler, U. (2004). The changing debate on internationalization of higher education. Higher Education, 48, 5-26. https://doi.org/10.1023/B:HIGH.0000033771.69078.41

Teichler, U. (2006). Changing structures of the higher education systems: The increasing complexity of underlying forces. Higher Education Policy, 19(4), 447-461. https://doi.org/10.1057/palgrave.hep.8300133

Theodore, J. D. (2014). The process of globalization In Latin America. International Business \& Economics Research Journal (IBER), 14(1), 193-198. https://doi.org/10.19030/iber.v14i1.9044

Tiffin, J., \& Rajasingham, L. (2003). The global virtual university. London: Routledge Falmer. https://doi.org/10.4324/9780203464670 
Tight, M. (2015). Theory development and application in higher education research: The case of academic drift. Journal of Educational Administration and History, 47(1), 84-99. https://doi.org/10.1080/00220620.2015.974143

Tilak, J. B. G. (2008). Transition from higher education as a public good to higher education as a private good: The saga of Indian experience. Journal of Asian Public Policy, 1(2), 220-234. https://doi.org/10.1080/17516230802094593

Tjeldvoll, A. (2010). The service university. Managing Global Transitions, 8(4), 423-447.

Tomasevski, K. (2005). Globalizing what: Education as a human right or as a traded service? Indiana Journal of Global Legal Studies, 12(1), 1-78. https://doi.org/10.2979/gls.2005.12.1.1

Tooley, J. (2004). The global education industry (2nd ed.). London: Institute of Economic Affairs.

Turpin, T., \& Cooper, R. (2005). Technology, adaptation, and public policy in developing countries: The 'ins and outs' of the digital divide. Minerva, 43(4), 419-427. https://doi.org/10.1007/s11024-005-2471-x

Ullman, E. (2012). The social media network. Community College Journal, 82(3), 24-28.

Vaiva, M. (2004). Globalization and higher education organizational change: A framework for analysis. Higher Education, 48(4), 483-510. https://doi.org/10.1023/B:HIGH.0000046711.31908.e5

Van der Wende, M. C. (2001). The international dimension in national higher education policies: What has changed in Europe in the last five years? European Journal of Education, 36(4), 431-441. https://doi.org/10.1111/1467-3435.00080

Van der Wende, M. C. (2003). Globalisation and access to higher education. Journal of Studies in International Education, 7(2), 193-206. https://doi.org/10.1177/1028315303007002006

Van Vught, F. A. (2008). Mission diversity and reputation in higher education. Higher Education Policy, 21(2), 151-174. https://doi.org/10.1057/hep.2008.5

Walsh, T. (2011). Unlocking the gates: How and why leading universities are opening up access to their courses. Princeton, NJ: Princeton University Press. https://doi.org/10.1515/9781400838578

Weber, L. E., \& Duderstadt, J. J. (Eds.) (2012). Global sustainability and the responsibilities of universities. London, England: Economica.

Weller, M., \& Anderson, T. (2013). Digital resilience in higher education. European Journal of Open, Distance and e-Learning, 16(1), 41-65.

Youngs, G. (Ed.) (2013). The digital world: Connectivity, creativity and rights. New York, NY: Routledge.

Zajda, J. (2015). Globalisation and its impact on education and policy. In Second International Handbook on Globalisation, Education and Policy Research (pp. 105-125). Netherlands: Springer. https://doi.org/10.1007/978-94-017-9493-0_7

Zhao, J. J., Alexander, M. W., Perreault, H., Waldman, L., \& Truell, A. D. (2009). Faculty and student use of technologies, user productivity, and user preference in distance education. Journal of Education for Business, 2, 206-212. https://doi.org/10.3200/JOEB.84.4.206-212

Zhu, C. (2015). Organisational culture and technology-enhanced innovation in higher education. Technology, Pedagogy and Education, 24(1), 65-79. https://doi.org/10.1080/1475939X.2013.822414.

Zott, C., Amit, R., \& Massa, L. (2011). The business model: Recent developments and future research. Journal of Management, 37(4), 1019-1042. https://doi.org/10.1177/0149206311406265

\section{Copyrights}

Copyright for this article is retained by the author(s), with first publication rights granted to the journal.

This is an open-access article distributed under the terms and conditions of the Creative Commons Attribution license (http://creativecommons.org/licenses/by/4.0/). 